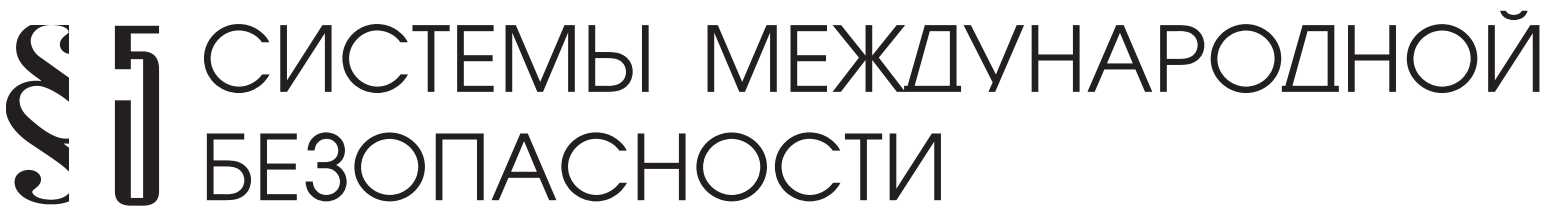

Никитина И.Э

\section{ИНСТИТУЦИОННО-ПРАВОВАЯ ЗНАЧИМОСТЬ ВКЛЮЧЕННОСТИ КРИМИНАЛИСТИЧЕСКОЙ БАЗЫ ДАННЫХ И УЧЕТА В СИСТЕМУ СОТРУДНИЧЕСТВА ГОСУДАРСТВ-ЧЛЕНОВ ЕВРОПЕЙСКОГО СОЮЗА ПО УГОЛОВНЫМ ДЕЛАМ}

\begin{abstract}
Аннотация: В работе автор подробно рассматривает институционно-правовую значимость включенности криминалистической базы данных и учета в систему сотрудничества государств-членов Европейского Союза по уголовным делам. Анализируется проиесс создания информационной системы автоматизированного обмена криминалистической информацией, принципы, основы и субъекты, институционной механизм обеспечения и реализаиии положений Прюмского договора. Обеспечение межгосударственного процесса обмена криминалистической информацией, стимулирование положительных и минимизация негативных последствийхранения и передачи информачии, включая персональные данные личности. При помощи диалектического метода, а также традищионо важной роли сравнительно-правовой методики изучения законодательства, призванного обеспечить борьбу с преступностью, в статье проводится оценочный анализ слабых и сильных сторон Прюмского договора. Основными выводами проведенного исследования является тот факт, что сотрудничество правоохранительных органов государств-членов Европейского Союза по уголовным делам перешло на новый качественный уровень развития. Отмечается, что с вступлением в силу Прюмского договора процесс унификации законодательства в области защиты прав и свобод человека получил свое дальнейтее развитие. Выводы статьи могут быть полезны правоприменительным органам при раскрытии и расследовании трансграничных преступлений.
\end{abstract}

Ключевые слова: Система международной безопасности, информаиионная безопасность, криминалистические базы, сотрудничество, Прюмский договор, защита персональных данных, криминалистическая информация, автоматизированный обмен, унификачия законодательства, расследование преступлений.

Abstract: This work discloses institutional and legal significance of the involvement of forensic database and criminal record in the system of cooperation European Union member states in criminal cases. Analyzes the process of creating an information system automated exchange of criminal information, principles, foundation and entities, and institutional mechanism to ensure the implementation of the Treaty of Prum. Providing an interstate process of exchange criminal information, to promote the positive and minimize the negative effects of storage and transmission of personal information. Using the dialectical method, as well as the traditional importance of comparative legal methods of studying legislation to implement the fight against crime, this work presents an evaluation of the strengths and weaknesses of Treaty of Prum. Since the Treaty of Prum entry into force the process forward harmonization of legislation for the protection of human rights and freedoms was further developed. Conclusions of this work may be useful to law enforcement authorities in the detection and investigation of cross-border crimes.

Keywords: System of international security, Information security, Criminal database, Cooperation, Treaty of Prum, Protection of personal data, Criminal information, Automated exchange, Unification of legislation, Criminal investigation.

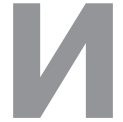

нститут информационной безопасности по факту своей международно-правовой значимости в своем логически юридическом содержании касается и предметно применим в аспекте взаимодействия государств-членов Европейского Союза по пресечению международной преступности. По своему сущностному содер- жанию универсальная система международной безопасности в параметрах своего субъектного состава и предмета регулирования в институционно-правовом плане упорядочена в формате верховенства права $[3-4,10,14,24]$. Основополагающим элементом построения международной нормативной системы исключительно и предметно в режиме верховенства 
права является выполняемость международных обязательств независимо от источника их возникновения на основе принципа добросовестности bona fides $[1,5,9,19,22,26,27]$.

Обеспечение внутренней безопасности в Европе всегда являлось приоритетным направлением деятельности Европейского Союза (далее - ЕС). В условиях интернационализации организованной преступности важное место в сфере борьбы с ней принадлежит модернизации системы межгосударственного обмена информацией при раскрытии и расследовании трансграничных преступлений. По мнению зарубежных экспертов, четко налаженное международное информационное взаимодействие правоохранительных органов европейских государств - необходимая предпосылка для организации их совместной деятельности в противодействии преступности. Получение своевременной правовой помощи по уголовным делам, включая криминалистическую, оперативно-розыскную и иную информацию, является одним из ключевых моментов успеха в деле обеспечения правопорядка и законности на территории европейских государств.

9 июня 1997 г. Совет ЕС одобрил резолюцию (обязательство) по обмену ДНК-профилями [20]. В этой резолюции странам - членам ЕС предлагалось создать национальные базы данных таким образом, чтобы была обеспечена их совместимость со всеми другими европейскими базами данных. С этой целью предлагалось использовать одинаковые стандарты для их построения и функционирования. Выбранный стандарт должен быть оптимальным для системы информационного обмена криминалистической значимой информацией между правоохранительными органами европейских стран. Информационный обмен следовало ограничить лишь сравнением ДНК-профилей, в результате которого возможно ответить на следующие вопросы: содержатся ли генетические данные конкретного человека в национальной базе данных ДНК; принадлежат ли биологические объекты, изъятые с места происшествия, подозреваемому лицу.

Однако проделанной в данном направлении работы еще не достаточно для принятия согласованных норм по использованию ДНК-информации как доказательства в уголовном процессе европейских стран.

В 1997 г. ЕС инкорпорировал Шенгенскую конвенцию / второе Шенгенское соглашение 1990 г. [23] в правовую систему ЕС в рамках «третьей опоры». С этого времени Шенгенская конвенция включает в себя некоторые компенсационные меры, такие как упрощение взаимодействия между полицейскими органами стран-участниц (Раздел III Шенгенской конвенции 1990 г.). Данный шаг был предпринят для поддержания и развития ЕС как территории, способной обеспечить свободу, безопасность и право свободного передвижения личности [7].

В дополнение к Шенгенскому соглашению Бельгией, Германией, Испанией, Францией, Люксембургом, Нидерландами и Австрией была подписана Прюмская конвенция (от 17 июля 2005 г. / Шенгенское соглашение III - далее Прюмский договор) [10], вступившая в законную силу в мае 2008 г. Статья 39 указанной Конвенции предусматривает взаимную помощь по уголовным делам и прямой обмен информацией (например, ДНК-профилями, номерами машин и т.д.), за исключением той, которая связана с личными данными. Следует отметить, что доступ к информации ограничен, т.е. предоставляется только исключительно необходимая информация в рамках уголовного расследования преступлений.

В сфере полицейского сотрудничества основными целями ЕС являются: предоставление правоохранительным органам государств-членов ЕС доступа к релевантной информации (например, к базам данных дактилоскопической и геномной информации или иммиграционной базе данных - Visa Information System (VIS)); качественное улучшение сотрудничества органов полиции в рамках общей системы защиты персональной информации; развитие европейской модели обмена информацией.

В условиях интернационализации организованной преступности важное место в сфере борьбы с ней принадлежит модернизации системы межгосударственного обмена информацией при раскрытии и расследовании трансграничных преступлений. По мнению зарубежных экспертов, четко налаженное международное информационное взаимодействие правоохранительных органов европейских государств - необходимая предпосылка для организации их совместной деятельности в противодействии преступности. Получение своевременной правовой помощи по уголовным делам, включая криминалистическую, оперативно-розыскную и иную информацию, является одним из ключевых моментов успеха в деле обеспечения правопорядка и законности на территории европейских государств.

Прюмский договор вступил в законную силу 26 августа 2011 г., несмотря на то, что далеко не все страны-члены ЕС успели модернизировать национальные базы для обмена криминалистической информацией в автоматическом режиме, чем нарушили положения ст.10 Договора о ЕС, поскольку принцип добросовестности обязывает государства-члены ЕС воздерживать- 
ся от любых мер, которые мешают достижению целей соответствующих соглашений.

Прюмский договор включает в себя 4 основныхблока.

Создание системы автоматизированного поиска криминалистической информации (геномной и дактилоскопической из национальных баз данных всех государств-членов; а также из баз данных регистрационных номеров транспортных средств). Данный механизм можно охарактеризовать не только как прогрессивное начало в сотрудничестве государств-членов в сфере обмена информацией по уголовным делам, но и как одну из наиболее труднодостижимых целей ЕС.

Обеспечение процесса обмена информацией в целях предупреждения преступлений, особенно при проведении крупномасштабных мероприятий против трансграничной организованной преступности и терроризма (главы 3 и 4 Договора).

Полицейское сотрудничество (гл. 5 Договора предусматривает качественное развитие сотрудничества органов внутренних дел государств-членов в борьбе с преступностью, как например, предоставление полиции права на осуществление своих полномочий на территории иностранного государства).

Защитта информации (гл. 6 Договора) [21].

В соответствии с отчетом Еврокомиссии перед Европейским парламентом и Советом ЕС по приграничному сотрудничеству, в частности борьбе с терроризмом и трансграничной преступностью, в свете реализации положений Прюмского договора от 23 июня 2008 г. в ЕС была проведена работа по оценке ситуации после решения Совета ЕС 2008/615/JHA и более года после истечения поставленного срока его полного выполнения государствами-членами. В это же время Совет принял решение 2008/616/ JНА для реализации решения 2008/615/ JНА (далее-Прюмские решения). В ноябре 2009 г. к обоим Прюмским решениям присоединилась Исландия и Норвегия. По прошествии более года с момента вступления в силу Прюмского договора только 18 стран-членов ЕС заявили, что технические условия в их странах позволяют осуществлять автоматическую передачу и прием ДНК-информации, и еще пять стран готовы начать автоматизированный обмен геномной информацией по уголовным делам в 2013 г. Что касается автоматизированных систем, предназначенных для передачи и поиска дактилоскопической информации, то здесь ситуация оказалась значительно сложнее, поскольку всего 14 стран-членов на указанный момент могли осуществлять обмен дактилоскопической информацией с другими государствами-членами.
По статистическим данным, предоставленным Европейской комиссией, с момента вступления в силу Прюмского договора ежегодно в среднем с помощью автоматизированной системы обмена дактилоскопической информацией идентифицируется 2500 человек, находится соответствие ДНК профилей в 20700 случаев. Ежегодное среднестатистическое количество запросов между странами по транспортным средствам, в которых находится нужная информация, составляет 260200 [11]. Полученные результаты показывают, что процесс автоматизированного информационного обмена криминалистической информацией по уголовным делам между правоохранительными органами стран-членов ЕС успешно действует, а положения Прюмского договора прошли апробацию.

Внедрение и апробация положений Прюмского договора в европейских странах вызвало немало трудностей как юридического, так и технического характера. Профессор Эрик Топфер (Eric Töpfer, ФРГ) справедливо заметил, что половина стран, входящих в ЕС, не была готова к вступлению в силу Прюмского договора менее года до установленного срока (август 2011 г.) в том числе из-за политических разногласий в национальных парламентах государств по имплементации положений Прюмского договора в национальные законодательства, административных барьеров, касающихся пределов компетенции и ответственности должностных лиц правоохранительных органов при размещении, хранении, передаче и приеме биоинформации, а также недостаточности человеческих и финансовых ресурсов. Более того, по меньшей мере десять стран испытывали трудности технического характера, поскольку их национальные информационные системы в той или иной степени оказались несовместимы с общеевропейскими и подлежали полной замене. Другими словами, присоединение к информационной системе Прюм требовало не только времени, но и финансовых затрат. Как показало научное исследование, проведенное специалистами Бельгии, средняя стоимость вступления страны в информационную систему Прюм приблизительно стоила два миллиона евро. Для стран, в которых не было действующей национальной базы данных ДНК до 2008 г., таких как Италия, Греция, Мальта или Ирландия, стоимость указанной процедуры, вероятно, была еще выше.

С целью преодоления возникающих проблем некоторые европейские страны, продвигающие Прюмский договор, предоставляли необходимую помощь отстающим в реализации Прюмского договора государствам. Например, Германия создала 
Мобильную группу помощи (Mobile Competence Team), а Австрия стала инициатором службы технической поддержки в Европоле. В рамках Европола в январе 2012 г. была основана служба помощи по реализации Прюмского договора, на которую возложены обязанности оказания помощи государствамчленам в передаче криминалистической информации. Важными сферами информационного обмена являются установка программного обеспечения, упрощение стандартных процедур, апробирование системы и ввод ее в эксплуатацию в передающих странах.

Нельзя не отметить, что одним из проблемных аспектов информационного обмена по уголовным делам остаются вопросы защиты персональных данных, что связано с приоритетом в политике ЕС соблюдения прав и свобод личности, но с другой стороны усиление безопасности в ЕС стало основным направлением в развитии европейского пространства свободы, безопасности и правосудия. И как следствие проблемы - необходимость разработки мер, направленных на обеспечение совместимости указанных целей ЕС в соответствии с принципом пропорциональности. Режим Прюмского договора подвергается критике со стороны правозащитников за ущемление прав и свобод граждан за так называемый «function creep» (постепенное расширение пределов использования системы сверх целей, для которых она была создана, особенно в тех случаях, когда это ведет к вмешательству в личную жизнь), а также за существующий риск создания полицейского государства и дальнейшее ухудшение положения жертв таких преступлений, как торговля людьми или жестокое обращение с детьми. В этом контексте особое значение придается защите персональных данных и ответственности за ее разглашение. Однако, в Европейском Союзе информации, доступной для широкой общественности, касающейся сотрудничества правоохранительных органов в области обмена криминалистической информацией по уголовным делам, включая ДНК-информацию, недостаточно. Отсутствует общественно доступный сервис или сайт в Интернете, которые информирует общество о достигнутом прогрессе в вопросах обмена криминалистической биоинформацией (исключение составляют Куратор голландской ДНК базы данных / the Custodian of the Dutch DNA database/ и австрийское министерство внутренних дел).

С другой стороны нельзя и недооценивать значение ДНК в доказывании по уголовным делам. Получение геномной информации - пример судебно-экспертного исследования, который позволил упростить расследования большого числа традиционных преступлений. Технология выделения ДНК-профилей была разработа- на английской лабораторией в 1985 г. [16]. За последние 30 лет доказательства, полученные в результате проведения судебно-геномной экспертизы (ДНК-анализ), сравнительно нового вида судебно-биологического исследования, связанного с отождествлением личности и биологического родства на основе специальных знаний в области криминалистики, молекулярной биологии и генетики человека, стали обычной практикой при рассмотрении дел в суде.

В США Программа «Невиновность» использует ДНК-информацию с целью доказать невиновность осужденных людей черной расы и людей, принадлежащих этническим меньшинствам. Так, беспристрастное изучение уголовных дел с использованием современных технологий привело к оправданию осужденных в 261 случае после вынесения вердикта о невиновности на основании результатов ДНКанализа, их них - 17 человек были приговорены к смертной казни. В среднем срок тюремного заключения, отбытый «оправданными» заключенными, составляет 13 лет, и почти в 40 процентах таких случаев настоящий преступник был найден с использованием ДНК-информации. Так, программа «Невиновность» причисляет вышесказанное к «основательным провалам» в работе системы уголовного правосудия США: «Есть общее во всех этих случаях: от проблем глобального характера, таких как бедность, до расовых предрассудков в работе уголовного правосудия, таких как неумение различать свидетелей, непоследовательная или неточная работа криминалистов, излишнее усердие полиции и прокуратуры, и неумелая адвокатура» [12].

На практике обеспечение совместимости основных целей ЕС в большинстве случаев вызывает среди государств-членов ЕС определенное смешение интересов в ту или иную сторону. Так, Закон «Об уголовном правосудии» Великобритании 2003 г. (The Criminal Justice Act) позволяет отбирать материал для ДНК-анализа у всех лиц, подвергшихся задержанию, по любому виду зарегистрированного правонарушения, включая, например, попрошайничество, нахождение в общественных местах в пьяном виде, нарушение общественного порядка, участие в незаконных демонстрациях, за исключением проступков, связанных с неправильной парковкой. Положения закона вызвали определенную обеспокоенность у правозащитников, в связи с неоправданным расширением круга лиц, подвергающихся процедуре отбора биологических образцов с последующим их хранением в национальной базе ДНК.

По мнению Алека Джеффриза (Alec Jeffreys), разработчика методики производства ДНК-анализа 
и дактилоскопических экспертиз и исследований, в самом начале, когда создавалась база данных, она содержала информацию о преступниках, и в случае совершения ими рецидива, по хранящимся биологическим образцам их можно было идентифицировать. В настоящее время сотни тысяч людей, чьи биологические данные внесены в информационную систему, - это невиновные граждане, которые вызвали интерес у полиции из-за того, что им было предъявлено обвинение, которое впоследствии не было подтверждено. С его точки зрения - это дискриминационно (Программа «Today, 2006) [8].

Прюмский договор не содержит правовых норм, относительно оснований отбора и последующего занесения в национальные базы данных дактилоскопической и ДНК-информации, обмена биоинформацией среди стран-участниц договора, сроков ее хранения и условий для ее удаления из информационных систем. Поэтому среди европейских государств, присоединившихся к Прюмскому договору, отмечается наличие расхождений в законодательствах и правоприменительных практиках.

К моменту вступления в силу Прюмского договора Национальная база данных ДНК Англии и Уэльса (NDNAD) содержала более пяти миллионов ДНК персональных профилей (subject profile) при населении в 53 млн. чел., база данных ДНК Шотландии содержала 236,000 таких профилей при населении в 5 млн. чел., а база данных ДНК Польши - 27,772 при населении в 38 млн. чел. Статистика показывает, что численность населения стран прямо не связана с количеством граждан, чья биоинформация хранится в национальных базах данных. Все дело в различиях в законодательных актах, которые были приняты в разное время (например, акты об учреждении и деятельности криминалистических баз данных ДНК введены в Нидерландах в 1994г., в Австрии в 1997 г, а в Португалии в 2008 г.). Кроме того, правовые основания для отбора ДНК профилей в разных странах отличны. Если в Англии и Уэльсе биообразцы могут быть взяты у арестованных за совершение проступков, таких как появление в общественном месте в нетрезвом виде, попрошайничество, нарушение общественного порядка и т.п., то во Франции ДНК образцы отбираются только у подозреваемых и осужденных за совершение насильственных и имущественных преступлений. В Бельгии ДНК-профили подозреваемых лиц не заносятся в национальную базу данных ДНК, а ДНК-профили осужденных включаются в базу за совершение преступлений против личности.

Проведенный анкетный опрос среди членов Европейской сети криминалистических учреждений
(ЕСКУ), которая была создана в 1993 г. с целью объединения усилий ведущих криминалистических учреждений европейских стран в разработке новых криминалистических средств и методов, обмена научными программами, возможностью доступа к базам данных криминалистических учетов, подготовкой специалистов по единому стандарту, показал, что в большинстве европейских стран на взятие биологического материала требуется разрешение компетентного органа, производящего уголовное преследование, или следственного судьи. Однако респонденты из Франции и Испании сообщили, что в их странах отбор биологического материала возможен только с согласия физического лица. В Нидерландах взятие биологических образцов у подозреваемых лиц без их согласия возможно только в определенных случаях. Согласно голландскому законодательству, образцы могут быть взяты без согласия подозреваемого только в тех случаях, когда рассматриваемое преступление предусматривает лишение свободы на срок 8 и более лет, или если оно относится к определенной категории преступлений, как, например, сексуальные преступления [17].

Конечно, далеко не все подозреваемые в совершении преступлений сотрудничают с органами предварительного расследования. Поэтому имеющиеся расхождения в национальных законодательствах, регулирующих порядок производства судебных экспертиз и исследований в европейских странах, в частности, процедуру получения биологических образцов для сравнительных исследований, не способствуют эффективной борьбе с трансграничной преступностью. Подобные расхождения частично могут быть объяснены культурными различиями в развитии европейских стран. Некоторые страны (например, Нидерланды) придают большое значение конфиденциальности в вопросах сбора доказательств, поэтому требования к отбору образцов для сравнительных исследований весьма строги по сравнению с другими странами. Однако в том случае, когда достижения науки и техники сделают возможным отбор биологических образцов без медицинского вмешательства (например, слюны вместо крови), порог требований к их отбору естественно будет снижен. Это должно будет привести к проведению ДНК-анализа по более широкому кругу преступлений. Взятие образцов слюны у людей во многих странах рассматривается как насилие (violation) над человеком. Эти различия в оценке уровня инвазивности при получении ДНК различных частей тела человека имеют отношение к различному историческому, политическому и культурному наследию, а также различным подходам к защите прав человека. 
Таким образом, можно сделать вывод, что оценивая законность и достоверность результатов произведенных судебных экспертиз и исследований в чужой стране, суду следует принимать во внимание методы исследования и обстоятельства, при которых получены образцы для сравнительных исследований, а также то, каким образом проведено само исследование.

В 2008 г. Европейский Суд по правам человека постановил, что необоснованное расширение круга лиц, у которых отбираются биологические образцы, которые впоследствии заносятся в НБД ДНК, вступает в противоречие со ст. 8 Конвенции Совета Европы о защите прав человека и основных свобод. Так, Решение Европейского Суда привело в Великобритании к пересмотру законодательства и периоду консультаций, к ответственности правительства в соответствии с законом «О преступности и безопасности» 2010 г. (The Crime and Security Act), последующему переизбранию правительства и принятию закона «О защите свобод» 2012 г. (The Protection of Freedoms Act).

Каждый имеет право на личную жизнь, и любое вмешательство со стороны публичных властей в осуществление этого права, должно осуществляться в соответствии с законом. Так, в обязанность государствчленов Совета Европы входит защита определенных этических ценностей, таких как свобода, равенство и право на личную жизнь. Однако вмешательство публичных властей в частную жизнь человека посредством отбора, хранения и использования его биологических данных, допускается «в интересах национальной безопасности и общественного порядка, экономического благосостояния страны, в целях предотвращения беспорядков или преступлений, для охраны здоровья или нравственности или защиты прав и свобод других лиц» [6].

Несмотря на то, что британские суды поддерживают правовые основания отбора и хранения профилей ДНК и дактилокарт, Европейский суд по правам человека принял иное решение: он счел, что хранение в течение неопределенного биологических данных людей, не признанных виновными в совершении преступлений, является нарушением ст. 8 Европейской конвенции по правам человека.

Так, в деле С. и Марпер против Соединенного Королевства (S \& Marper v Unites Kingdom, 2008) обвиняемые были оправданы, в связи с чем, они потребовали у властей удаления их персональной информации из НБД ДНК. Им было отказано на том основании, что законодательство Великобритании позволяет хранить биологические образцы и ДНК-профили в течение неопределенного срока. Европейский суд по правам человека счел, что общая политика в Англии, Уэльса и Северной Ирландии по хранению ДНК профилей и дактилокарт в течение неопределенного времени, невзирая на окончательные результаты судебного следствия, несоразмерна основаниям, которые дают право властям нарушать запрет о неприкосновенности личной жизни граждан.

Конечно, криминалистическая информация является движущим фактором в раскрытии и расследовании преступлений, а также в их предупреждении, но именно биологические образцы являются потенциальными носителями информации личного и семейного характера, а также сведений о состоянии здоровья и некоторой информации о поведенческих характеристиках.

Наффилдский совет (Nuffield Council) (2007) считает, что предоставление частным компаниям права проводить ДНК - анализ, например, аналитическим лабораториям, облегчает утечку информации. Обеспокоенность общественности в связи с нарушением прав человека только усиливается, поскольку многие частные судебно-экспертные лаборатории проводят генетический анализ для организаций, в числе которых Управление по вопросам иммиграции МВД Великобритании (The Home Office Immigration Directorate), Управление по опеке над детьми (The Child Support Agency) и Управление по вопросам окружающей среды, продуктам питания и сельскохозяйственным вопросам (The Department for Environment, Food and Rural Affairs), которые могут потенциально обеспечивать различным общественным объединениям, не входящим в систему уголовного правосудия, доступ к биометрической информации о личности. В этой части Европейский суд по правам человека считает, что нарушается право граждан на частную жизнь, однако он соглашается с тем, что хранение дактилоскопической информации и ДНК-профилей способствует целям предупреждения преступности [18].

Таким образом, с принятием Прюмского договора в европейских странах начался автоматизированный процесс обмена криминалистической информацией, вследствие которого эффективность сотрудничества правоохранительных органов в сфере юстиции и внутренних дел значительно повысилась. Кроме того, режим Прюм позволяет в рамках Европы проводить сравнительные исследования следов с нераскрытых мест преступлений; выявить причастных к ним лиц, зарегистрированных под различными фамилиями в разных государствах и, возможно, устанавливать их настоящие данные; вести розыск по лиц по поступающим запросам об их аресте или получения информации о местонахождении. 
В связи с вышеизложенным можно рассматривать Прюмский договор как общеевропейское средство борьбы с преступностью, которое не только выводит трансграничное сотрудничество в сфере юстиции и внутренних дел на новый качественный уровень, но и обеспечивает поддержание общеевропейского правопорядка и безопасности в рамках пространства свободы, безопасности и правосудия Европейского Союза.

Следует отметить, что информационная система Прюм позволяет сотрудникам правоохранительных органов или представителям судебной власти в странах, где криминалистическая база данных находится не в ведении полиции, осуществлять поиск биоинформации в соответствующих базах данных иных европейских государств на соответствие изъятого биологического материала и иных следов с мест происшествий (например, следов пальцев неустановленных лиц). При выявлении совпадений с информацией, содержащейся в базе данных иностранного государства, запрашивающая сторона связывается с контактным пунктом указанной страны, где было выявлено указанное соответствие, и запрашивает уточняющие данные.

В некоторых случаях, когда в профилях ДНК получены совпадения, запрашивающая сторона может провести анализ на подтверждение совпадений, то есть, провести повторный анализ образца ДНК, чтобы уменьшить шанс автоматизированных совпадений, таких как ложно положительные, что в связи с огромным количеством ДНК профилей в базах данных во всей Европе стало встречаться довольно часто.

В случае автоматизированного совпадения отпечатков пальцев система работает иначе. В рамках Прюм данные об отпечатках пальцев рассматриваются как оцифрованные «дактокарты установленных лиц, дактилокарты неустановленных лиц, следы пальцев и ладоней, латентные следы, а также образцы таких следов (закодированный детальный протокол ввода отпечатков пальцев)». После передачи оцифрованные дактилоскопические данные сравниваются на основе алгоритмов. Этот процесс выявляет ряд возможных совпадений по отдельно взятому следу (частному отпечатку). Дело обстоит именно так, потому что поиск совпадений по отпечаткам пальцев влечет за собой сравнение полных отпечатков (отпечатка целого пальца, или пальцев, или ладони, при высоком качестве сравнительного материала в базах данных), в то время как на месте преступлений обычно изымаются частичные или латентные следы. Наиболее вероятные совпадения затем интерпретирует дактилоскопист. Таким образом, процесс выявления совпадений влечет за собой сравнение образцов следов и отпечатков «вручную». Это длительный процесс, который трудно себе представить, учитывая возможное количество совпадений между следами, изъятыми на месте преступления, и оцифрованными отпечатками или дактилокартами в базах данных государств-членов $\mathrm{EC}$, выявленных при помощи автоматизированного процесса. Если возможное совпадение следов пальцев будет установлено, ресурсы, необходимые для дальнейшего анализа, всегда предоставляются запрашивающей стороной.

Помимо политического решения Европейского Союза о тесном сотрудничестве в борьбе с трансграничной преступностью, технические условия реализации Прюмского договора включали в себя несколько важных аспектов. Когда характеризуют Прюмский договор, особое внимание уделяют гармонизации технологических практик, протоколов и стандартов. Так, например, в области дактилоскопии «эре Прюма» предшествовали несколько систем и инфраструктур для трансграничного обмена данными. В контексте Прюмского договора было принято, что его претворение в жизнь частично будет базироваться на уже существующих инфраструктурах.

Передача дактилоскопических данных в другие государства, являющиеся участницами договора, осуществляется через Систему автоматизированной идентификации отпечатков пальцев (Automated Fingerprint Identification System, AFIS), основывающуюся на стандартах, опубликованных Интерполом и Национальным институтом США по стандартам и технологиям. Эти стандарты, называемые «Формат данных для взаимообмена информации об отпечатках пальцев» (так называемые ANSI/NIST-ITL 12011), не были «предусмотрены для ручного ввода и интерпретации: скорее они были предназначены для передачи информации между информационными системами». Фактический обмен дактилоскопическими данными проходит через несколько систем, разработанных в последние два десятилетия. Ключевой инфраструктурой в данном контексте является система Евродак (Eurodac), в которой хранятся отпечатки пальцев лиц, беженцев, просящих о предоставлении политического убежища, и частично незаконных иммигрантов. Она разработана в соответствии с постановлением Совета ЕC 2725/2000, и за ее функционирование несет ответственность специализированное подразделение Европейской Комиссии. Информационная система Евродак состоит из центральной базы данных, содержащей оцифрованные отпечатки пальцев, а также некоторой информации персонального характера о том, кому принадлежит отпечаток (страна происхождения в ЕС; пол, место 
и дата прошения о предоставлении политического убежища или место и дата задержания лица; номер дела; дата снятия отпечатков пальцев; дата передачи отпечатков в центральное подразделение Евродак).

Дактилоскопическую информацию содержит также еще одна недавно разработанная система визовой информации (Visa Information System, VIS). Ее основная цель - оказать содействие в проведении общей визовой политики и недопускать незаконные операции с визами, а именно, практику, используемую гражданами стран, не входящих в ЕС, которым отказано в визе какой-то страной, входящей в Шенген, чтобы обратиться в другую страну, входящую в Шенген, до тех пор, пока какая-нибудь страна не выдаст визу.

Что касается ДНК профилирования и баз данных, то ведущие ученые в области криминалистики и судебной экспертизы, объединенные Европейской сетью криминалистических учреждений (European National Forensic Science Institutes, ENFSI) и специализирующиеся на «ДНК типировании», в 1988 г. создали Европейскую группу «ДНК типирования» (European DNA Profiling Group, EDNAP), целью которой была гармонизация практик и стандартов «ДНК типирования» в Европе. В самом начале работы группы «ДНК типирования» применяемые технологии имели серьезные технические недостатки, а также не имели должной научной и процедурной стандартизации и зачастую неверно интерпретировались. Таким образом, первые ДНК технологии не предусматривали использование стандартных процедур и делали невозможным сохранение ДНК-профилей в цифровом виде.

В начале 1990-х генетики открыли так называемые короткие тандемные дупликации (short tandem repeats, STRs), которые вскоре стали рассматриваться как потенциально очень значимые для криминалистической работы, главным образом, из-за трех своих характеристик. Во-первых, STRs представляли частично разрушенные (международное договорное количество локусов) биологические образцы, подходящие для ДНК типирования. Во-вторых, STRs могли быть точно определены и выражены в цифрах. Наконец, третье достоинство STRs - их хранение в цифровой форме в базах данных ДНК. Криминалисты Европейской группы ДНК типирования приступили к стандартизации методов, протоколов и результатов STR анализа, что, в конечном счете, привело к выявлению нескольких STR локусов, которые стали использовались во всей Европе. В конечном счете, они стали рассматриваться как Европейский стандартный набор (European Standard Set, ESS) локусов, рекомендованный к применению в рамках ЕС. Таким образом, условия для трансграничного обмена ДНК- информацией стало делом совместных усилий генетиков-криминалистов разных стран и должностных лиц, определяющих политику в области юстиции и внутренних дел ЕС. Кроме того, несколько компаний, занимающихся биотехнологиями, таких как Promega и Applied Biosystems, разработали так называемые мультиплексные комплекты для ДНК типирования, которые позволяли увеличить малые количества ДНК с помощью так называемой полимеразной цепной реакции (ПЦР) (polymerase chain reaction, PCR) - с семью локусами STR ESS, и которые применялись до середины 1990-х. На основе ESS можно получить выборочные возможности соответствия (random match probabilities, RMP) 1 из 50 миллионов (это означает, что профиль произвольно выбранного человека из всего населения (генеральной совокупности) совпадет с данным ДНК профилем в пропорции 1: 50000 000).

Но перспективы трансграничного обмена на европейском уровне параллельно с расширяющимися правилами отбора биоинформации с последующим размещением ее в национальных базах данных ДНК могло привести к риску «ошибочно положительных» (так называемых случайных совпадений ДНК профилей), означающих ошибочное совпадение ДНК следа с ДНК конкретного лица, не имеющего отношения к совершенному преступлению. Обзор, опубликованный Европейской сетью криминалистических учреждений (ENFSI) в июле 2011 г., показал, что база данных ДНК в странах, подписавших Прюмский договор, содержала более 9.2 млн. справочных профилей и более одного миллиона ДНК-следов. Сравнивание этих профилей с другими привело бы к вероятности возможных совпадений. Случайные совпадения при использовании семи локусов ESS постепенно стали повторяться. C целью исправления ситуации, Европейская группа ДНК типирования (EDNAP) предложила дополнить ESS еще пятью STR локусами, что и было одобрено Резолюцией Совета Европы в 2009 г. в основе которой лежит положение о том, что чем выше количество сравниваемых локусов, тем ниже статистический шанс получения «случайных» совпадений. Все компании, занимающихся биотехнологиями и производящие комплекты STR-PCR, разработали новый комплект для анализа ДНК, содержащий двенадцать ESS локусов, предназначенный для совершенствования ДНК-анализа.

Создание и стандартизация ESS, содержащих двенадцать STR локусов, представляет собой результат совместной работы и сотрудничества генетиковкриминалистов Европы. К этому в той же мере причастны компании занимающихся биотехнологиями, предоставившие так называемые мультиплексы для 
ДНК типирования с необходимым ESS, и, наконец, это было одобрено Резолюцией ЕС. Дальнейшие усилия по стандартизации и гармонизации создали и продолжают создавать условия для эффективного трансграничного обмена ДНК профилями.

В любом случае использование в борьбе с преступностью большего числа механизмов, таких как национальная ДНК база данных, система автоматизированной идентификации отпечатков пальцев (AFIS) и режима Прюм, приведет к раскрытию большего количества преступлений.

В противоположность мнению о Европейском Союзе как политическом и географическом союзе, режим Прюм - это больше, чем сумма его частей, поэтому его можно рассматривать как систему. Во-первых, следует обратить внимание на гетерогенность (разнородность) режима Прюм, его роли в гармонизации национальных законодательств, регламентирующих правила сбора и хранения информации при раскрытии и расследовании преступлений, преобразованию различных цифровых наборов данных криминалистической биоинформации (AFIS, базы данных ДНК) в стандартизированные и взаимосвязанные базы данных, а также содействие более тесной работе различных учреждений системы уголовного правосудия, имеющих различия в нормах права касательно отбора и хранения криминалистической биоинформации. Во-вторых, понятие «система» включает природу связи между указанными выше элементами, акцентируя внимание на историчности и материальности элементов в рамках системы Прюм. Риторически-программый уровень - еще один элемент этой системы. Прюмский договор представляется как возникший из стратегической потребности «переход на более высокий уровень трансграничного сотрудничества, особенно в борьбе против терроризма, трансграничной преступности и незаконной миграции». Этот диагноз стратегической потребности, отраженный в исторических и программных документах, интересен сам по себе, поскольку в истории Европы период, когда свободное передвижение людей перекрывалось плотной сетью пограничного контроля, длился менее одного столетия. До Первой мировой войны пограничный контроль встречался редко, и проблема трансграничной незаконной миграции была темой ожесточенных дискуссий по вопросу кочевого населения. Поэтому пограничный контроль следует рассматривать скорее как исключение, чем правило, в истории Европы. Поскольку режим Прюм возник и соответствует вновь возникшей стратегической необходимости, то следует заметить, что он в то же время создает и новые стратегические потребности: например, потребность в гармонизации политических ценностей, технологий и практик. Эти вновь созданные цели резонируют с востребованностью предупреждения международных преступлений и создания универсальной системы безопасности.

Осознанная потребность реагировать на угрозы, возникающие из отсутствия пограничного контроля в Европе, стимулировали инициативы по более тесному трансграничному сотрудничеству в вопросах борьбы против терроризма, трансграничной преступности и незаконной миграции. Прюмский договор обозначен как механизм для достижения указанных целей. Одной из обозначенных его функций является соединение огромного спектра разнородных исполнителей, юрисдикций, объектов и ценностей. Свобода передвижения - не цель сама по себе, она предназначена для обеспечения коллективного благосостояния, преуспевания и единения (общности).

Прюмский договор, как сформулировано в ежегодном отчете голландской базы данных, позволил органам уголовного правосудия европейских стран достичь цели Европейского Союза по построению общеевропейского пространства свободы, безопасности и правосудия, а именно, вместе противостоять современным вызовам и угрозам.

Согласно опросу, проведенному Европейской комиссией среди государств-участников Прюмского договора, была подтверждена юридическая значимость института автоматизированного межгосударственного обмена ДНК-информацией и информацией по транспортным средствам при раскрытии и расследовании преступлений [11].

Как показала практика, основными формами оперативного сотрудничества полицейских органов государств-членов ЕС являются: совместное патрулирование, осуществление общего контроля на дорогах, магистралях и иных важных транспортных инфраструктурах, обеспечение безопасности при проведении массовых мероприятий и мероприятий «высокого уровня», проверка документов и лиц, а также оказание технической помощи. Иные формы сотрудничества на практике встречаются нечасто.

Итак, в соответствии со ст. 21 Решения Совета ЕС (2008/616/JНА) оценка эффективности информационного обмена криминалистическими данными, в соответствии с главой 2 Решения Совета ЕС (2008/616/ JHA), должна проводиться регулярно. С этой целью каждое государство ежегодно передает статистические данные по результатам автоматического обмена криминалистической информацией в Генеральный Секретариат Совета ЕС, который на основании полу- 
ченных сведений готовит заключительный обзор за прошедший год, и в Комиссию ЕС.

Генеральный Секретариат предоставляет, таким образом, общую статистику за каждый год по автоматизированному обмену ДНК-данными и дактилоскопической информацией, а также данными о транспортных средствах. В структуре ЕС также была создана специальная рабочая группа по обмену информацией и защите данных (Working Group on Information Exchange and Data Protection (DAPIX).

К достоинствам Прюмского договора следует отнести и то, что с его вступлением в силу стали совершенствоваться и пополняться национальные базы данных ДНК, о чем свидетельствуют статистические данные по количеству ДНК-профилей и количеству направляемых и принимаемых запросов в европейских странах.

Приведенные статистические данные подтверждают положение о том, что с принятием Прюмского договора обмен криминалистической информацией по уголовным делам среди стран-участниц существенно возрос. Принятые в рамках ЕС общие стандартные процедуры передачи и приема информации также способствовали созданию национальных баз данных геномной информации в странах, в которых ранее их не было.

В целях организации процесса передачи и приема дактилоскопической информации с целью предупреждения и расследования уголовных дел государства-участницы Прюмского договора разрешают компетентным лицам из других государств через национальные контактные пункты (НКП) получать доступ к автоматизированной системе дактилоскопической информации с полномочиями на проведение поиска совпадений дактилоскопических данных. Более подробная информация для последующего сравнения должена быть подтверждена запрашиваемым государством-членом ЕС. Так называемая процедура “post-hit", то есть, предоставление дальнейшей информации о человеке и иная информация, имеющая отношение к справочным данным в случае такого совпадения, осуществляется в соответствии с государственными законами запрашиваемого государства-участника Прюмского договора.

Рабочая группа по обмену информацией и защите данных (DAPIX) на совещании 27 октября 2011 г. утвердила стандартные процедуры по автоматизированному обмену информацией о дактилоскопических данных. Статистические данные по дактилоскопической информации предоставляются по следующим критериям: количество исходящих от государства запросов; данные по типу сравнения; количество исходящих от государства запросов и количество найденных при этом совпадений. В соответствии с п. 8.3 главы 2 Приложения к решению Совета ЕС 2008/616/JНА приняты следующие критерии сравнения дактилоскопической информации:

ТР/ТР-дактилокартысравниваются с дактилокартами;

LT/TP - следы пальцев неустановленного лица сравниваются с дактилокартами;

LP/PP - следы ладоней неустановленного лица сравниваются с отпечатками ладоней;

TP/UL - дактилокарты сравниваются со следами с нераскрытых мест преступлений;

LT/UL - следы пальцев неустановленного лица сравниваются со следами с нераскрытых мест преступлений;

PP/ULP - отпечатки ладоней сравниваются со следами рук с нераскрытых мест преступлений;

LP/ULP - следы ладоней неустановленного лица сравниваются со следами рук с нераскрытых мест преступлений.

\section{Регистрационные данные о транспортных средствах.}

Для предупреждения и расследования уголовных дел и иных правонарушений, входящих в юрисдикцию суда или прокуратуры государства-члена ЕС в сфере уголовных расследований или обеспечения общественной безопасности, положения Прюмского договора содержат нормы, позволяющие компетентным органам государств-участников договора через национальные контактные пункты (НКП) иметь доступ к национальным базам данных транспортных средств друг друга с полномочиями на проведение автоматизированного поиска данных, относящихся к владельцу транспортного средства или компании, предоставляющей услуги, а также к иным данным о транспортном средстве.

В 2015 г. начал свое существование Евразийский экономический Союз (ЕАЭС). В целях обеспечения правопорядка и безопасности на территории государств-участников ЕАЭС целесообразно соверщенствовать формы сотрудничества в сфере борьбы с преступностью, принимая во внимание зарубежный опыт обеспечения межгосударственного обмена криминалистической информацией по уголовным и административным делам. Остается проблемой отсутствие единых автоматизированных баз данных о транспортных средствах и государственных регистрационных знаках со странами СНГ, что не позволяет средствам автоматической фиксации нарушений правил дорожного движения регистрировать ПДД Российской Федерации, допускаемые на транспортных средствах с регистрационными знаками стран СНГ.

Международно-правовая включенность Российской Федерации в процесс взаимодействия с 


\section{Системы международной безопасности}

государствами-членами ЕС по линии противодействия международной преступности содействует поддержанию универсальной системы безопасности.

Таким образом, международно-правовой статус Российской Федерации оказывает реальное значение (в формате включенности в универсальную систему безопасности) для продвижения в предметном режиме современного миропорядка задач по противодействию международной преступности. Осознавая значимость координации международного сотрудничества в части пресечения преступности как социального феномена, Российская Федерация в формате своей включенности в универсальную систему безопасности осуществляет действенное содействие государствам-членам Европейского Союза в плане эффективного функционирования общеевропейской системы безопасности. Общим результатом многостороннего сотрудничества европейских государств по линии противодействия международной преступности в объективном порядке выступает режим международной законности и правопорядка как общее достояние всего мирового сообщества в целом.

\section{Библиография:}

1. Дмитриева Г.К. Принцип добросовестности в современном международном праве / Правоведение. 1979. № 6. - С. 85-86.

2. Дмитриева Г.К. Становление принципа недопустимости злоупотребления правом / Советский ежегодник международного права. 1987. М, 1988. - С. $114-117$.

3. Иванов И.С. Верховенство права в международных отношениях / Междунар. жизнь. 2000. № 12. - С. 62-67.

4. Каламкарян Р.А. Господство права Rule of Law в международных отношениях. M., 2004. - C. 256-269.

5. Каламкарян Р.А. Принцип добросовестности в современном международном праве. М., 1990.

6. Конвенция о защите прав человека и основных свобод // Сборник документов Совета Европы «Защита прав человека и борьба с преступностью» 2-е дополненное издание. М., 2005. - С. 49.

7. МВД Финляндии - Министерство управления, регионального развития и внутренней безопасности. Хельсинки, 2000.

8. Blakemore B., Blake Ch. Can the National DNA Database be effective and comply with human rights legislation? / Police Journal, Great Britain, 2010, Vol. 85, № 3, P. 192.

9. Cheng B. General Principles of Law as Applied by International Courts and Tribunals, London, 1953. P. 121-136.

10. Dicey A.V. Introduction to the Study of the Law of Constitution. London, 1960. P. 183-206.

11. Dok. Nr. 11367/12 Council of the European Union, Brussels, 20 June 2012.

12. Innocence Project (nd) [Online] http://www.innocenceproject.org/know/ (29 October 2010).

13. The Hague Program: strengthening freedom, security and Justice in the EU / Official Journal of European Communities, 2005. Vol. 48. C. 53. - P. 1-14. Some remarks on Schengen III / Statewatch Bulletin, 2005, 17 July. Доступно на сайте: http:www. statewatch.org/news/2005/jul/17Schengen-III.htm.

14. Jackson S.W. The rule of law among nations / The Rule of Law. Dallas, 1961. - P. 71-86.

15. Jacqué J. - P. Eléments pour une theorie de l'acte juridique en droit international public. Paris, 1972. - P. 171

16. Jeffreys A.J. et. al. Individual specific 'fingerprints' of human DNA, The Hague, 1985. P. 76-79.

17. Lia van der Westen. Legal Regulations Governing Forensic Scientific Methods // Harmonisation in Forensic Expertise. An inquiry into the desirability of and opportunities for international standards, Thela Thesis, The Hague, 2000. - P. 284.

18. Nuffield Council on Bioethics (2007) The Forensic Use of Bio Information: Ethical Issues. Nuffield Council on Bioethics: London [Online] htpp://www.nuffieldbioethics.org/sites/default/files/The\%20forensic\%20use \%20of\%20bioinformation $\% 20$ \%20ethical\%20issues.pdf (14 December 2010).

19. Oppenheim L. International Law / Ed. by H. Lauterpacht. London, 1958.Vol. 1 P. 345-347; 21. Oppenheim L. Op. Cit. P. $345-347$.

20. Official Journal C 193/2 of 24.06.1997.

21. OL L 210, 200886 .

22. Paul V. The Abuse of Rights and Bona Fides in International Law / Österreichishe Zeitschrift für öffentliches Recht und Völkerrect. 1977. Bd. 28 N. 1/2. S. 125, 127, 128-129.

23. Protocol integrating the Schengen acquis into the framework of the EU, 19 June 1990 / Official Journal C 30, 10 November 1997. Доступно на сайте: www.europa.eu.

24. Renouf A. The rule of law in international affairs / Australian Foreign Affairs Record. 1975. July. P. 395-405.

25. Rousseau Ch. Droit International Public. Paris, 1970. Vol. 1-P. 382-383.

26. Schwarzenberger G. International Law. London. 1976. P. 382-383.

27. Zoller E. La bonne foi en droit international public. Paris, 1977. - P. 350.

28. Г. Г. Шинкарецкая Европейский союз и Европейская конвенция о защите прав человека и основных свобод// Международное право и международные организации / International Law and International Organizations. - 2012. - 1. - C. 54 - 64.

\section{References (transliterated):}

1. Dmitrieva G.K. Printsip dobrosovestnosti v sovremennom mezhdunarodnom prave / Pravovedenie. 1979. № 6. - S. 85-86.

2. Dmitrieva G.K. Stanovlenie printsipa nedopustimosti zloupotrebleniya pravom / Sovetskii ezhegodnik mezhdunarodnogo prava. 1987. M, 1988. - S. $114-117$. 
DOI: $10.7256 / 1811-9018.2016 .3 .14768$

При цитировании этой статьи сноска на dоі обязательна

Право и политика $3(195) \cdot 2016$

3. Ivanov I.S. Verkhovenstvo prava v mezhdunarodnykh otnosheniyakh / Mezhdunar. zhizn’. 2000. № 12. - S. 62-67.

4. Kalamkaryan R.A. Gospodstvo prava Rule of Law v mezhdunarodnykh otnosheniyakh. M., 2004. - S. 256-269.

5. Kalamkaryan R.A. Printsip dobrosovestnosti v sovremennom mezhdunarodnom prave. M., 1990.

6. Blakemore B., Blake Ch. Can the National DNA Database be effective and comply with human rights legislation? / Police Journal, Great Britain, 2010, Vol. 85, № 3, P. 192.

7. Cheng B. General Principles of Law as Applied by International Courts and Tribunals, London, 1953. P. 121-136.

8. Dicey A.V. Introduction to the Study of the Law of Constitution. London, 1960. P. 183-206.

9. Jackson S.W. The rule of law among nations / The Rule of Law. Dallas, 1961. - P. 71-86.

10. Jacqué J. - P. Eléments pour une theorie de l'acte juridique en droit international public. Paris, 1972. - P. 171

11. Jeffreys A.J. et. al. Individual specific 'fingerprints' of human DNA, The Hague, 1985. P. 76-79.

12. Lia van der Westen. Legal Regulations Governing Forensic Scientific Methods // Harmonisation in Forensic Expertise. An inquiry into the desirability of and opportunities for international standards, Thela Thesis, The Hague, 2000. - P. 284.

13. Oppenheim L. International Law / Ed. by H. Lauterpacht. London, 1958.Vol. 1 P. 345-347; 21. Oppenheim L. Op. Cit. P. $345-347$.

14. Paul V. The Abuse of Rights and Bona Fides in International Law / Österreichishe Zeitschrift für öffentliches Recht und Völkerrect. 1977. Bd. 28 N. 1/2. S. 125, 127, 128-129.

15. Renouf A. The rule of law in international affairs / Australian Foreign Affairs Record. 1975. July. P. 395-405.

16. Rousseau Ch. Droit International Public. Paris, 1970. Vol. 1-P. 382-383.

17. Schwarzenberger G. International Law. London. 1976. P. 382-383.

18. Zoller E. La bonne foi en droit international public. Paris, 1977. - P. 350

19. G. G. Shinkaretskaya Evropeiskii soyuz i Evropeiskaya konventsiya o zashchite prav cheloveka i osnovnykh svobod // Mezhdunarodnoe pravo i mezhdunarodnye organizatsii / International Law and International Organizations. - 2012. 1. - C. $54-64$. 